\title{
ANALISIS PENYEBARAN PENYAKIT FILARIASIS MENGGUNAKAN MODEL SEIR DI PROVINSI SUMATERA UTARA
}

\author{
Muhammad Mukhlis' ${ }^{1}$ Fazrina Saumi², ${ }^{2}$ Ulya Nabilla ${ }^{3}$ \\ 1,2,3 Prodi Matematika, Fakultas Teknik, Universitas Samudra \\ ulya.nabilla@unsam.ac.id
}

\begin{abstract}
North Sumatra is one of the endemic areas of tropical diseases, one of which is filariasis. Filariasis or elephantiasis is a disease transmitted through mosquitoes and can cause permanent physical disability for sufferers. In 2015, there were 127 filariasis sufferers. This number has increased to 164 patients in 2017. As a prevention effort, the government provides mass treatment for people living in endemic areas of the disease. Therefore, this study aims to determine the model of spread and the effect of treatment on these communities. This study uses an SEIR model consisting of susceptible humans (S_h), infected humans (E_h), infected humans (I_h), and immune humans (R_h). The data used is data on filariasis sufferers in North Sumatra in 2010-2019, obtained from the North Sumatra Health Office. The data were analyzed based on the equilibrium point, stability, basic reproductive ratio, and numerical simulation. The results showed that based on the SEIR model, filariasis treatment could suppress transmission in endemic areas.
\end{abstract}

Keywords: Basic Reproductive Ratio, Filariasis, SEIR.

\begin{abstract}
ABSTRAK Sumatera Utara merupakan salah satu kawasan endemik dari penyakit tropis, salah satunya filariasis. Filariasis atau penyakit kaki gajah merupakan penyakit yang ditularkan melalui nyamuk dan dapat mengakibatkan kecacatan fisik permanen bagi penderitanya. Pada tahun 2015, terdapat 127 penderita filariasis. Jumlah tersebut semakin meningkat hingga mencapai 164 penderita di tahun 2017. Sebagai upaya penanggulangan, pemerintah memberikan pengobatan massal bagi masyarakat yang berada di kawasan endemik penyakit tersebut. Oleh karena itu, penelitian ini bertujuan untuk mengetahui model penyebaran dan pengaruh pengobatan bagi masyarakat tersebut. Penelitian ini menggunakan model SEIR yang terdiri atas manusia rentan $\left(S_{h}\right)$, manusia terjangkit $\left(E_{h}\right)$, manusia terinfeksi $\left(I_{h}\right)$ dan manusia kebal $\left(R_{h}\right)$. Data yang digunakan adalah data penderita filariasis di Sumatera Utara tahun 2010-2019, yang diperoleh dari Dinas Kesehatan Sumatera Utara. Data tersebut dianalisis berdasarkan titik kesetimbangan, kestabilan, basic reproductive ratio, dan simulasi numerik. Hasil penelitian menunjukkan bahwa berdasarkan model SEIR, pengobatan filariasis dapat menekan penularan di kawasan endemik.
\end{abstract}

Kata-kata Kunci : Basic Reproductive Ratio, Filariasis, SEIR. 


\section{PENDAHULUAN}

Filariasis atau penyakit kaki gajah merupakan penyakit menular yang menyebabkan kecacatan fisik. Lebih lanjut (Hasti Komaria et al., 2016) menyatakan filariasis merupakan penyakit infeksi menular yang disebabkan oleh cacing filaria melalui perantara nyamuk yang sudah terinfeksi. Gejala dari penyakit filariasis ini ditandai dengan demam disertai menggigil dan berkeringat, nyeri kepala, mual, muntah, dan nyeri otot (Masrizal, 2013). Penyakit ini bersifat menahun. Jika tidak mendapatkan pengobatan, penyakit menjadi kronis dan mengakibatan cacat menetap berupa pembesaran kaki, dan alat kelamin baik perempuan maupun laki-laki (Astuti et al., 2014). Berikut contoh penderita filariasis seperti pada gambar 1.

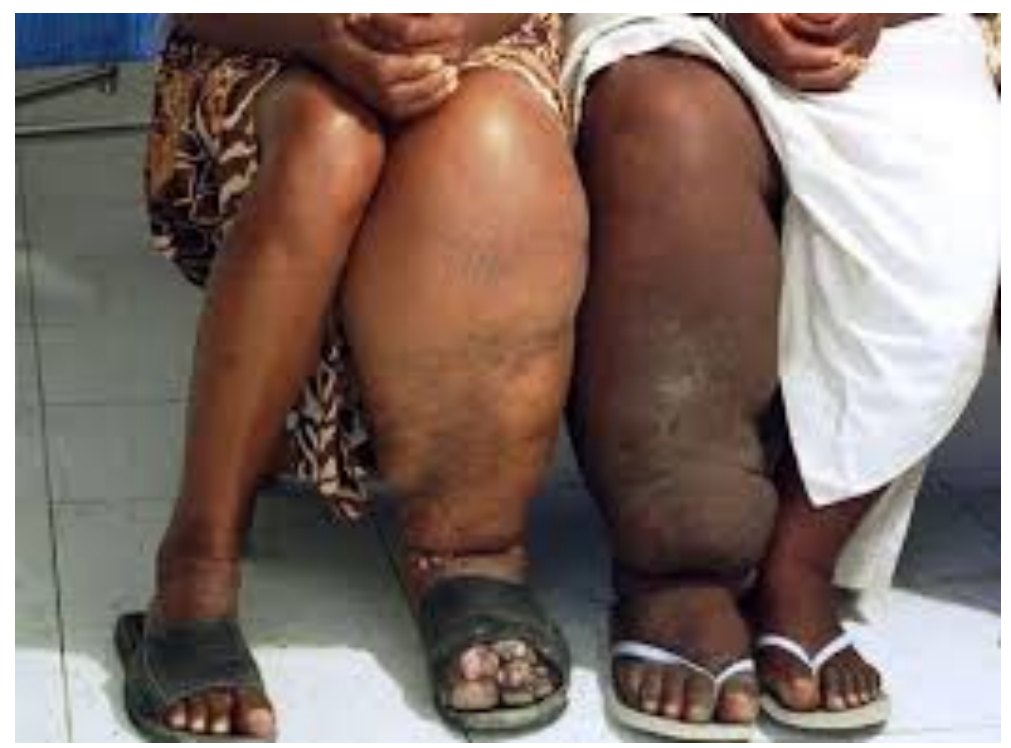

Gambar 1. Contoh penderita filariasis

Sumber : (Dinkes, 2017)

Pada tahun 2005 terdapat 8.243 kasus filariasis(Infodatin, 2019). (Kemenkes RI, 2018) menambahkan, penderita filariasis semakin meningkat hingga pada tahun 2017 mencapai 12.677 jiwa di seluruh kabupaten atau kota, termasuk Sumatera Utara. Sumatera Utara merupakan salah satu kawasan endemik dari penyakit tersebut. Pada tahun 2017 penderita filariasis di Sumatera Utara mencapai 164 jiwa(Kemenkes $\mathrm{Rl}, 2018)$.

Menurut (Nabilla, 2020) proses penyebaran filariasis melalui lima tahapan, yaitu pada tahap pertama, mikrofilaria Ll masuk ke dalam tubuh nyamuk ketika menghisap darah penderita. Kemudian pada tahap kedua, mikrofilaria L1 berkembang menjadi mikrofilaria L2. Pada tahap ketiga, Mikrofilaria L2 berkembang menjadi mikrofilaria L3 Mikrofilaria pada tahap inilah yang dapat menginfeksi manusia ketika nyamuk menghisap darah manusia tersebut. Selanjutnya pada tahap keempat, mikrofilaria L3 berkembang menjadi mikrofilaria L4. Pada tahap kelima, Mikrofilaria L4 berkembang menjadi cacing dewasa. Cacing dewasa tersebut akan menyumbat pembuluh limfe sehingga terjadi pembengkakan. Satu ekor cacing betina mampu 
menghasilkan sekitar 50.000 mikrofilaria L 1 setiap hari. Mikrofilaria ini juga dapat masuk ke tubuh nyamuk ketika terjadi gigitan. Cacing dewasa dapat bertahan dalam tubuh manusia mencapai sepuluh tahun. Proses penyebaran tersebut diilustrasikan seperti pada gambar 2.

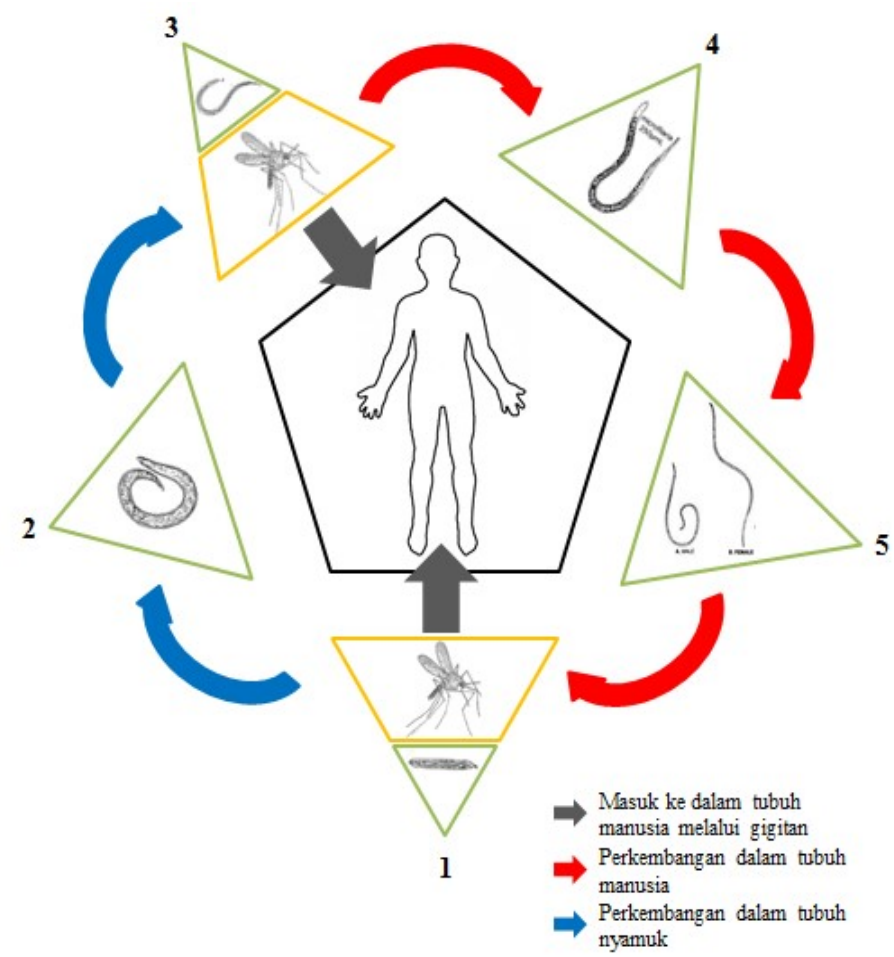

Gambar 2. Siklus transmisi filariasis

Sumber : (Nabilla, 2020)

Untuk menanggulangi penyebaran filariasis, pemerintah memberikan pengobatan gratis kepada semua masyarakat yang memenuhi syarat di suatu daerah yang terserang filariasis. Program ini dikenal dengan sebutan Pemberian Obat Pencegahan Massal Filariasis (POPM filariasis) (Setyaningtyas et al., 2017). Obat yang digunakan adalah Diethylcarbamazine (DEC) dan Doxycycline.

Berdasarkan latar belakang proses penyebaran penyakit tersebut, peneliti menggunakan model Susceptible, Expose, Infected, Recovered (SEIR) untuk mengkaji penyebaran filariasis, menganalisis kestabilan model di sekitar titik kesetimbangan, serta menganalisis pengaruh pemberian obat. Model Susceptible Expose Infected Recovered (SEIR) merupakan pengembangan dari model Susceptible Infected Recovered SIR (Sihotang et al., 2019). Model ini sering digunakan untuk menggambarkan transimisi penyebaran suatu penyakit.

\section{METODE PENELITIAN}

Data penelitian yang digunakan adalah data penderita filariasis pada tahun 2010 2019. Data tersebut diperoleh dari Dinas Kesehatan Sumatera Utara. Menurut (Effendy, 2013) alur penelitian digambarkan dalam skema flowchart seperti pada gambar 3. 


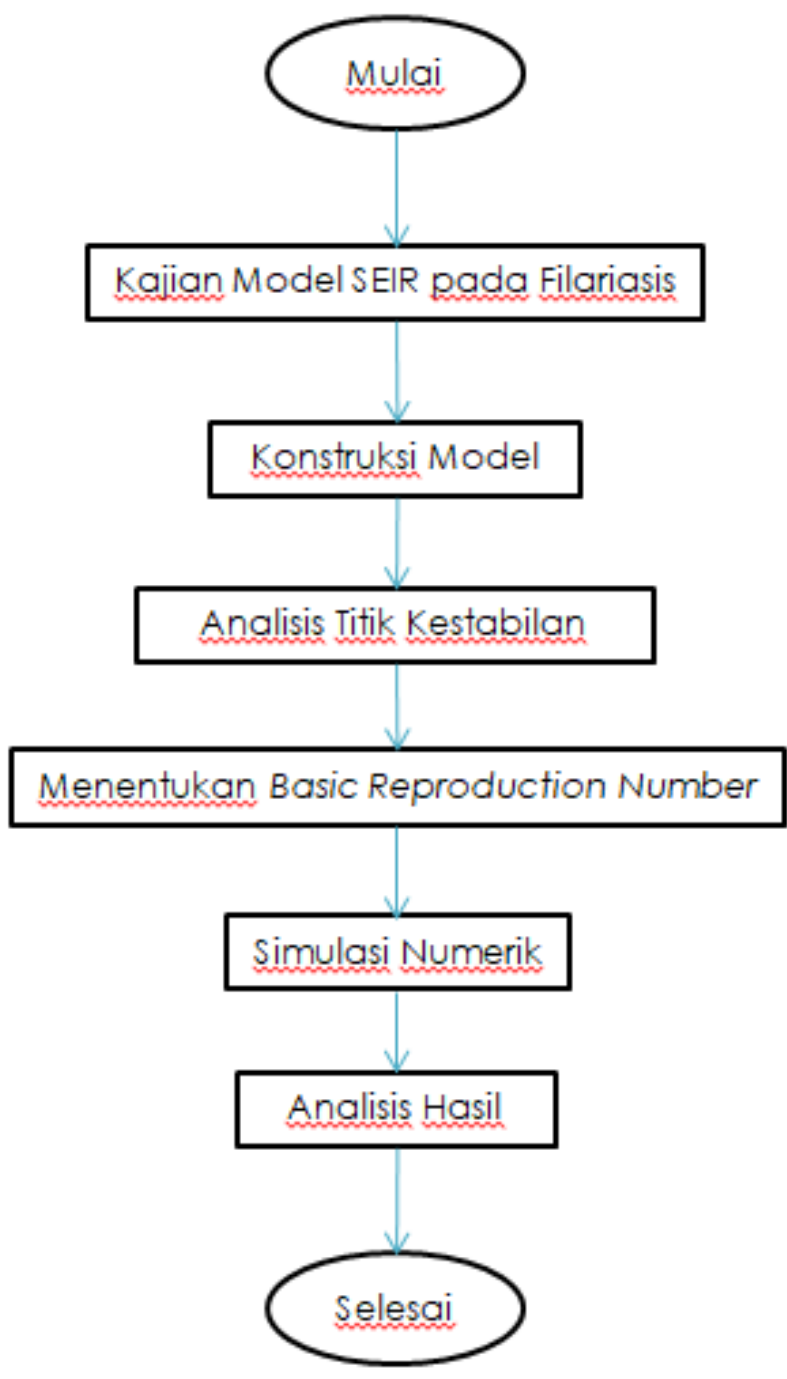

Gambar 3. Diagram Alur Penelitian

Penjelasan dari gambar 3 adalah sebagai berikut.

a. Penelitian dimulai dari mengkaji model SEIR (Susceptible, Expose, Infected, dan Recovered) pada penyakit filariasis.

b. Hasil kajian tersebut digunakan untuk mengkonstruksi model SEIR pada penyakit filariasis.

c. Model tersebut dianalisis titik kestabilan pada titik kesetimbangannya dengan menggunakan software Mapple. Hal ini dapat dilakukan dengan melihat tanda pada akar-akar polinomial karakteristik dari matriks Jacobian.

d. Selanjutnya dicari basic reproduction number yang diperoleh dari polinomial karakteristik bebas penyakit.

e. Kemudian dilakukan simulasi numerik.

f. Titik kestabilan, basic reproduction number, dan simulasi numerik dianalisis untuk memperoleh suatu kesimpulan.

Asumsi-asumsi dasar yang digunakan pada penelitian ini adalah sebagai berikut.

a. Laju kelahiran pada manusia dan nyamuk dianggap konstan.

b. Manusia yang telah terinfeksi penyakit filariasis tidak dapat sembuh dari penyakit. 
c. Manusia yang rentan terkena penyakit dapat langsung berpindah ke subpopulasi manusia yang kebal terhadap penyakit apabila pemberian obat pencegahan filariasis yang dilakukan berhasil dan langsung berpindah ke subpopulasi manusia yang terekspos apabila pemberian obat pencegahan filariasisyang dilakukan tidak berhasil.

d. Laju kematian manusia dan nyamuk pada setiap populasi dianggap konstan.

e. Pengaruh migrasi diabaikan sehingga penyebaran penyakit bersifat tertutup dalam suatu populasi.

f. Pengaruh pemberian obat pada manusia terinfeksi diabaikan sehingga tidak dapat berpindah ke manusia kebal.

Selain asumsi dasar, dibutuhkan pula pendefenisian variabel seperti pada tabel 1.

Tabel 1. pendefenisian variabel pada penelitian

\begin{tabular}{ccc}
\hline Variabel & Deskripsi & Satuan \\
\hline$S_{h}$ & Subpopulasi manusia yang rentan terhadap penyakit & orang \\
$E_{h}$ & Subpopulasi manusia yang terjangkit & orang \\
$I_{h}$ & Subpopulasi manusia yang terinfeksi & orang \\
$R_{h}$ & Subpopulasi manusia yang kebal terhadap penyakit & orang \\
$S_{v}$ & Subpopulasi nyamuk yang rentan terhadap penyakit & ekor \\
$I_{v}$ & Subpopulasi nyamuk yang terinfeksi & ekor \\
\hline
\end{tabular}

Sedangkan pendefenisian parameter, disajikan dalam tabel 2.

Tabel 2. pendefenisian parameter pada penelitian

\begin{tabular}{clc}
\hline Parameter & \multicolumn{1}{c}{ Deskripsi } & Satuan \\
\hline$A_{h}$ & Laju kelahiran alami pada populasi manusia (host) & orang/hari \\
$\mu_{h}$ & Laju kematian alami pada populasi manusia (host) & $1 /$ hari \\
$\gamma$ & Laju penyebaran penyakit & $1 /$ hari \\
$\theta$ & Laju eliminasi manusia yang terinfeksi penyakit filariasis & $1 /$ hari \\
$\delta$ & Laju perpindahan subpopulasi manusia & $1 /$ hari \\
$\alpha$ & Presentase keberhasilan pemberian $\quad$ obat & - \\
& pencegahan filariasispada populasi manusia & \\
$A_{v}$ & Laju kelahiran alami pada populasi nyamuk (vektor) & ekor/hari \\
$\mu_{v}$ & Laju kematian alami pada populasi nyamuk (vektor) & $1 /$ hari \\
$\beta$ & banyaknya kontak penularan penyakit & - \\
\hline
\end{tabular}

Sehingga diperoleh model penyebaran filariasis seperti pada persamaan 1.

$\frac{d S_{h}}{d t}=A_{h}-(1-\alpha) \gamma S_{h} I_{v}-\left(\mu_{h}+\alpha\right) S_{h}$

$\frac{d E_{h}}{d t}=(1-\alpha) \gamma S_{h} I_{v}-\left(\mu_{h}+\delta\right) E_{h}$

$\frac{d I_{h}}{d t}=\delta E_{h}-\mu_{h} I_{h}$

$\frac{d R_{h}}{d t}=\alpha S_{h}-\mu_{h} R_{h}$ 
$\frac{d S_{v}}{d t}=A_{v}-\beta \frac{S_{v}}{N} I_{h}-\mu_{v} S_{v}$

$\frac{d I_{v}}{d t}=\beta \frac{S_{v}}{N} I_{h}-\mu_{v} I_{v}$

Diagram model penyebaran tersebut adalah sebagai berikut.

$a S_{h}$

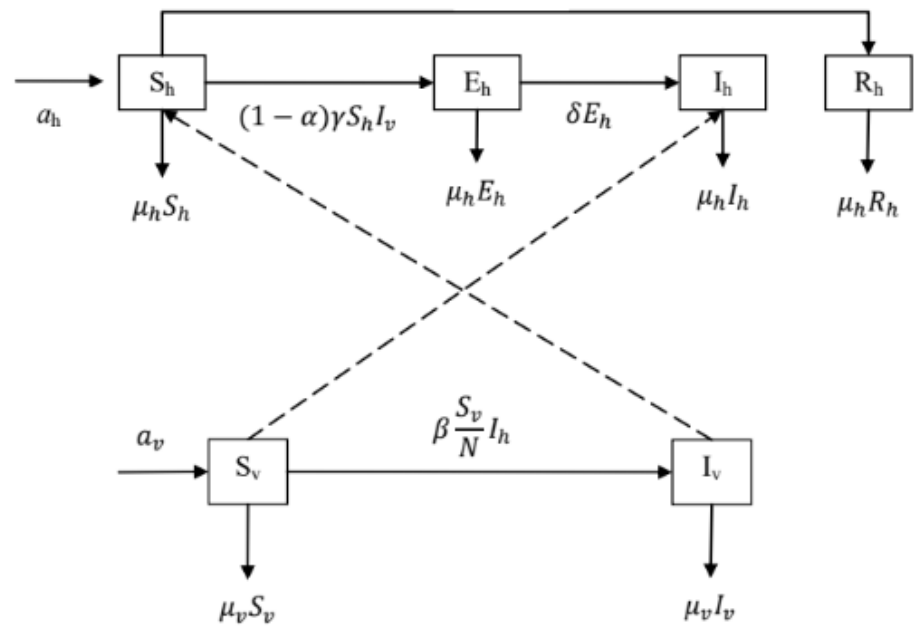

Gambar 4. Diagram penyebaran filariasis

\section{HASIL DAN PEMBAHASAN}

Untuk menganalisis model penyebaran filariasis, digunakan data-data yaitu $N=4500$; $A_{h}=0,01 ; A_{v}=0,1 ; \mu_{h}=0,05 ; \mu_{v}=0,008 ; \alpha=0,8 ; \gamma=0,0000034 ; \delta=0,09$, dan $\beta=$ 0,00014 .

\section{Analisa Kesetimbangan}

Berdasarkan hasil analisa titik kesetimbangan, menghasilkan dua titik kesetimbangan bebas penyakit dan titik kesetimbangan endemik penyakit, yaitu :

Titik Kesetimbangan Bebas Penyakit (TK1)

$T K_{1}=\left\{S_{h 1}=\frac{A_{h}}{\mu_{h}+\alpha}, E_{h 1}=0, I_{h 1}=0, R_{h 1}=\frac{\alpha A_{h}}{\left(\mu_{h}+\alpha\right) \mu_{h}}, S_{v 1}=\frac{A_{v}}{\pi_{v}}, E_{v 1}=0, I_{v 1}=0\right\}$

Titik ini menunjukkan kondisi penyakit punah.

Titik Kesetimbangan Endemik Penyakit (TK2)

$T K_{2}$

$=\left\{S_{h 2}=-\frac{\mu_{h}\left(\mu_{h}^{2} \mu_{v} n+\mu_{h} \delta \mu_{v} n+a_{h} \beta \delta\right)}{\delta\left(-\gamma a_{v}+\gamma \alpha a_{v}-\mu_{h} \mu_{v}-\alpha \mu_{v}\right) \beta}, E_{h 2}=\frac{P}{\left(-\gamma a_{v} a_{h}\right) \beta \delta}, I_{h 2}=\frac{P}{\left(-\gamma a_{v} \mu_{v}+Q\right) \mu_{h} \beta}, R_{h 2}\right.$

$=\frac{\alpha \mu_{v}\left(\mu_{h}^{2} \mu_{v} n+\mu_{h} \delta \mu_{v} n+a_{h} \beta \delta\right)}{\delta\left(-\gamma a_{v}+\gamma \alpha a_{v}-\mu_{h} \mu_{v}-\alpha \mu_{v}\right) \beta \mu_{h}}, S_{v 2}$

$\left.=\frac{n \mu_{h}\left(-\gamma a_{v} \mu_{h}-\gamma a_{v} \delta+\gamma \alpha a_{v} \mu_{h}+\gamma \alpha a_{v} \delta-\mu_{h}^{2} \mu_{v}-\mu_{h} \mu_{v} \delta-\alpha \mu_{v} \mu_{h}-\alpha \mu_{v} \delta\right)}{R}, I_{h 2}=\frac{P}{R}\right\}$

dengan :

$P=-\gamma \mathrm{a}_{\mathrm{v}} \mathrm{a}_{\mathrm{h}} \beta \delta+\gamma \mathrm{a}_{\mathrm{v}} \mathrm{a}_{\mathrm{h}} \beta \delta \alpha+\mathrm{n} \mu_{\mathrm{v}}^{2} \mu_{\mathrm{h}}^{3}+\mathrm{n} \mu_{\mathrm{v}}^{2} \mu_{\mathrm{h}}^{2} \delta+n \mu_{\mathrm{v}}^{2} \mu_{\mathrm{h}}^{2} \alpha+n \mu_{\mathrm{v}}^{2} \mu_{\mathrm{h}} \alpha \delta$ 
$Q=-\gamma \mathrm{a}_{\mathrm{v}} \delta+\gamma \alpha \mathrm{a}_{\mathrm{v}} \mu_{\mathrm{h}}+\gamma \alpha \mathrm{a}_{\mathrm{v}} \delta-\mu_{\mathrm{h}}^{2} \mu_{\mathrm{v}}-\mu_{\mathrm{h}} \mu_{\mathrm{v}} \delta-\alpha \mu_{\mathrm{v}} \mu_{\mathrm{h}}-\alpha \mu_{\mathrm{v}} \delta$

$R=\gamma\left(-\mu_{h}^{2} \mu_{v} n-\mu_{h} \delta \mu_{v} n+n \mu_{h}^{2} \alpha \mu_{v}+n \mu_{h} \alpha \mu_{h} \delta-a_{h} \beta \delta+a_{h} \beta \delta \alpha\right)$

Titik ini menunjukkan kondisi penyakit menjadi endemik atau menyebar luas.

\section{Analisa Kestabilan}

Dari hasil kestabilan model didapatkan nilai akar-akarnya yaitu $\lambda_{1}=\lambda_{2}=\mu_{h}-\alpha=$ $-0,075$ dan $\lambda_{3}=\lambda_{4}=\lambda_{5}=\lambda_{6}=-\mu_{h}=-0,05$. Semua nilai akar persamaan karakteristik polinom menunjukan bahwa titik bebas penyakit bersifat stabil.

\section{Analisa Basic Ratio reproductive $R_{0}^{d}$}

Dari persamaan karakteristik polinom diperoleh nilai eigen terbesar yaitu $R_{d}^{2}=$ $\frac{\mu_{v} \mu_{h}^{2}+\alpha \mu_{v} \mu_{h}}{\mu_{v}-2 \alpha}$. Dengan demikian dengan mensubstitusikan dengan nilai parameter maka diperoleh nilai $R_{d}^{2}=-0,0002$. Hal ini menunjukkan tidak terjadi endemik atau berada dikeadaan bebas penyakit yang akan ditandai dengan dengan menurunnya subpopulasi manusia terinfeksi.

\section{Simulasi dan Interpretasi Model}

Untuk melakukan simulasi digunakan data-data tambahan, yaitu $S_{h}(0)=14.415 .049$; $E_{h}(0)=157 ; I_{h}(0)=187 ; R_{h}(0)=11.532 .039 ; S_{v}(0)=3.000 ; I_{v}(0)=1.500$. Hasil simulasi menunjukkan bahwa pada awal tahun jumlah manusia rentan yaitu berkisar 14.415.049 jiwa hingga pada tahun ke-4 jumlah manusia rentan yaitu kurang dari 2.000.000. Hal ini dapat terjadi karena adanya pemberian obat pada manusia rentan dapat dilihat pada Gambar 5.

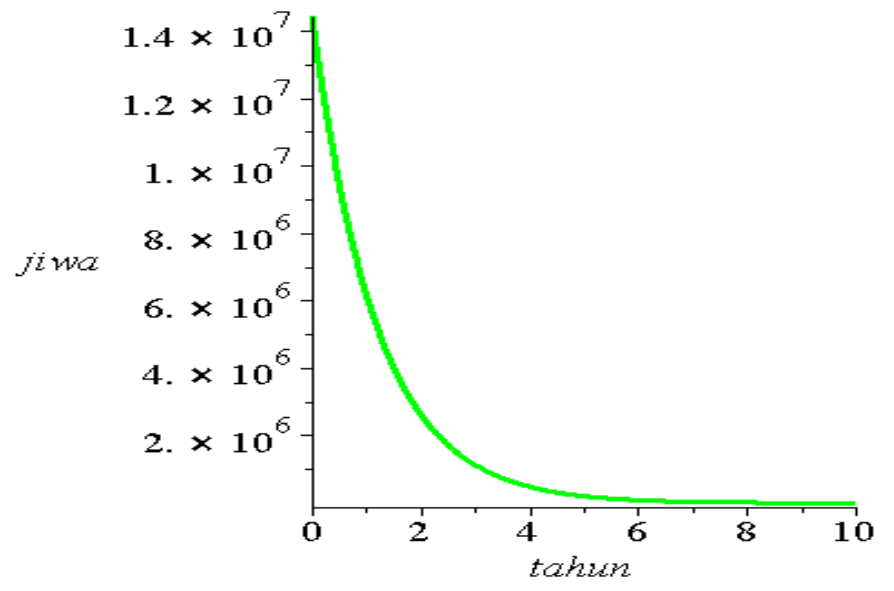

Gambar 5. Model Simulasi pada Manusia Rentan

Sedangkan pada jumlah populasi manusia terjangkit yaitu 157 jiwa mengalami peningkatan yang sangat cepat hingga pada tahun ke-4 jumlah manusia terjangkit yaitu lebih dari 2.000 jiwa, dapat dilihat pada Gambar 6. 


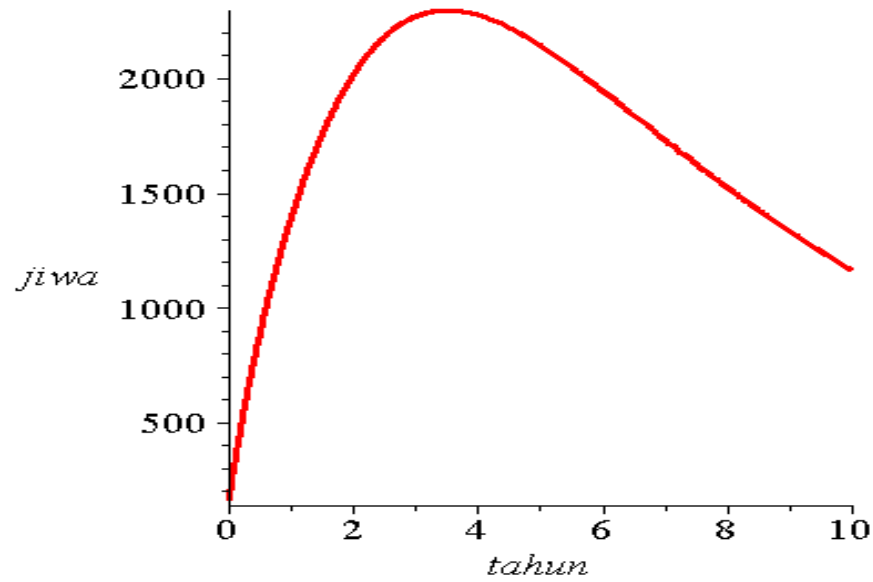

Gambar 6. Model Simulasi pada Manusia Terjangkit

Jumlah populasi manusia terinfeksi juga mengalami peningkatan yang sangat signifikan. Pada tahun pertama jumlah manusia terinfeksi yaitu 187 jiwa kemudian pada tahun ke-10 jumlah manusia terinfeksi yaitu lebih dari 1.200 jiwa dapat dilihat pada Gambar 7.

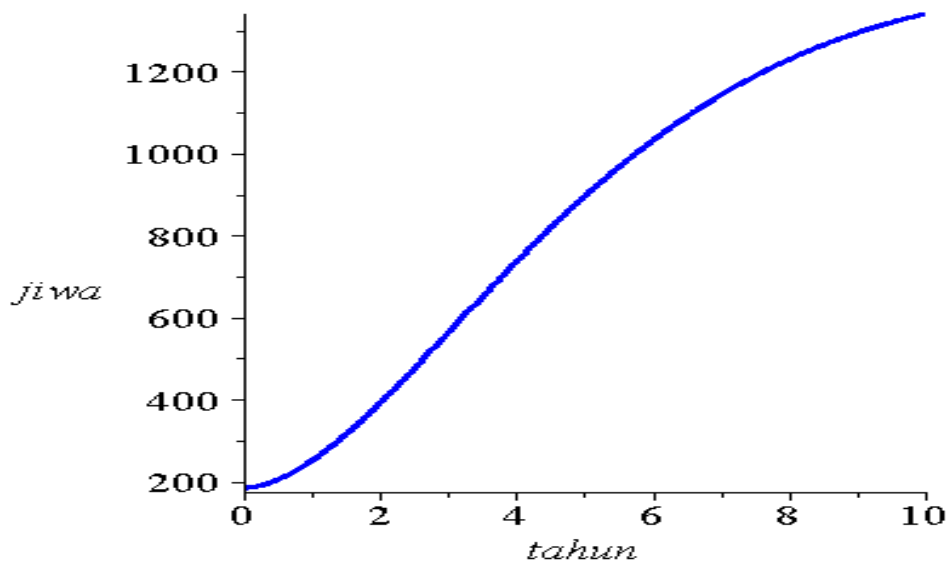

Gambar 7. Model Simulasi pada Manusia Terinfeksi

Pada tahun pertama jumlah manusia kebal yaitu lebih dari 12.000 .000 jiwa hingga pada tahun ke empat jumlah manusia kebal yaitu lebih dari 21.000.000. Hal ini disebabkan oleh keberhasilan pemberian obat pada manusia rentan.Akan tetapi pada tahun ke-5 sampai seterusnya jumlah manusia kebal mengalami penurunan hingga pada tahun ke-10 jumlah manusia kebal yaitu 16.000.000 dapat dilihat pada Gambar 8. 


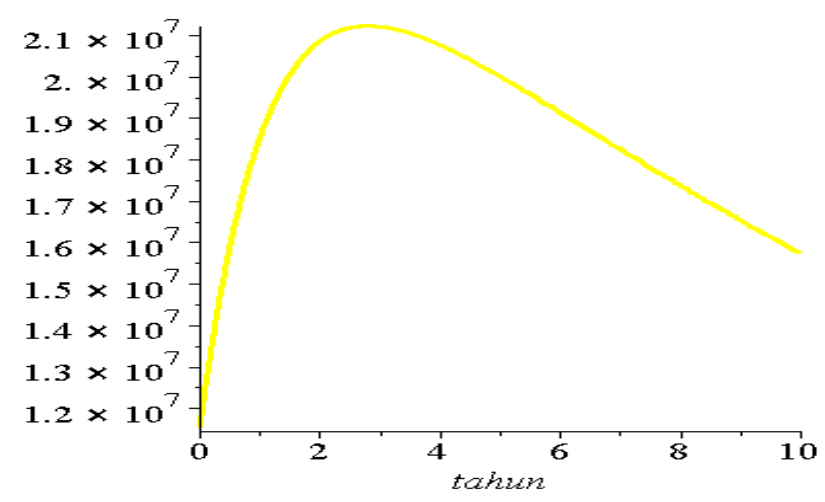

Gambar 8. Model Simulasi Manusia Kebal

Pada tahun pertama jumlah nyamuk rentan yaitu 3.0000 nyamuk, hingga pada tahun ke-10 jumlah nyamuk rentan mendekati titik stabil.Hal ini dikarenakan berkurangnya interaksi antara nyamuk rentan dan manusia terinfeksi dapat dilihat pada Gambar 9.

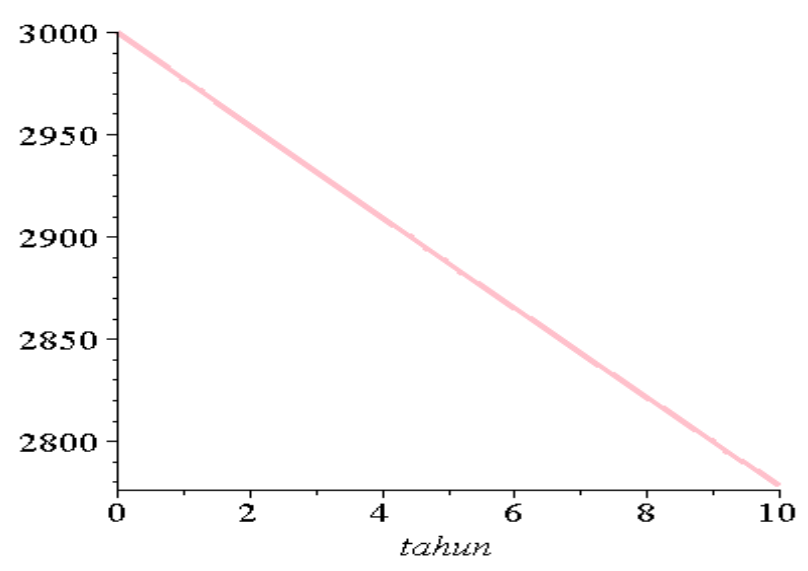

Gambar 9. Model Simulasi pada Nyamuk Rentan

Pada tahun pertama jumlah nyamuk terinfeksi yaitu 1.500 nyamuk hingga pada tahun ke-10 jumlah nyamuk terinfeksi yaitu mendekati titik stabil.Hal ini dikarenakan berkurangnya jumlah nyamuk rentan yang terinfeksi filariasis serta berkurangnya interaksi antara nyamuk terinfeksi dengan manusia rentan dapat dilihat pada Gambar 10.

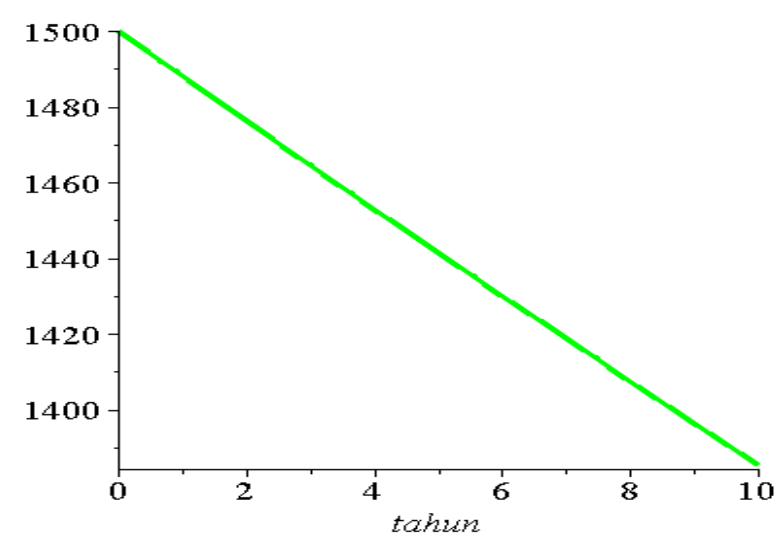

Gambar 10. Model Simulasi pada Nyamuk Terinfeksi 
Secara keseluruhan, dengan adanya pengobatan berdampak pada penurunan penyebaran filariasis. Hal ini tampak dari menurunnya jumlah penderita filariasis dan meningkatnya jumlah manusia kebal (recovered).

\section{KESIMPULAN DAN SARAN}

Berdasarkan analisis hasil penelitian, diperoleh kesimpulan bahwa model yang digunakan pada penyebaran filariasis adalah sebagai berikut.

$\frac{d S_{h}}{d t}=A_{h}-(1-\alpha) \gamma S_{h} I_{v}-\left(\mu_{h}+\alpha\right) S_{h}$

$\frac{d E_{h}}{d t}=(1-\alpha) \gamma S_{h} I_{v}-\left(\mu_{h}+\delta\right) E_{h}$

$\frac{d I_{h}}{d t}=\delta E_{h}-\mu_{h} I_{h}$

$\frac{d R_{h}}{d t}=\alpha S_{h}-\mu_{h} R_{h}$

$\frac{d S_{v}}{d t}=A_{v}-\beta \frac{S_{v}}{N} I_{h}-\mu_{v} S_{v}$

$\frac{d I_{v}}{d t}=\beta \frac{S_{v}}{N} I_{h}-\mu_{v} I_{v}$

Selanjutnya, pada manusia rentan terjadi penurunan yang sangat cepat yang dari manusia rentan ke manusia kebal akan penyakit. Hal ini dikarenakan adanya pengaruh pemberian obat pada manusia rentan. Oleh karena itu jika semakin tinggi persentase keberhasilan pemberian obat semakin tinggi maka akan semakin cepat penurunan terhadap manusia rentan tersebut.

Berdasarkan hasil penelitian diharapkan kepada pemerintah agar dapat melaksanakan kegiatan rutin pemberian obat dan kepada masyarakat agar rutin mengkonsumsi obat tersebut. Hal ini sebagai upaya pencegahan penularan penyakit filariasis.

\section{DAFTAR PUSTAKA}

Astuti, E. P., Ipa, M., Wahono, T., \& Ruliansyah, A. (2014). Analisis Perilaku Masyarakat Terhadap Kepatuhan Minum Obat Filariasis di Tiga Desa Kecamatan Majalaya Kabupaten Bandung Tahun 2013. Media Penelitian Dan Pengembangan Kesehatan, 24(4), 199-208.

Dinkes. (2017). Media Informasi Kesehatan. In Buku (37th ed.). Dinas Kesehatan Jawa Tengah.

Effendy. (2013). Analisis Stabilitas pada Penyebaran Penyakit DBD di Kabupaten Jember dengan Metode SIR Stokastik.

Hasti Komaria, R., Faisya, H. A. F., \& Sunarsih, E. (2016). Analysis of Physical Environment and Preventive Behavior Determinants Toward Genesis Filariasis Cases in the SubDistrict of Talang Kelapa and Sembawa, District of Banyuasin. Jurnal IImu Kesehatan Masyarakat, 7(2), 1-10. 
Infodatin. (2019). Situasi Filariasis di Indonesia. Infodatin.

Kemenkes RI. (2018). Profil Kesehatan Indonesia 2018. Kementerian Kesehatan Republik Indonesia.

Masrizal. (2013). Penyakit Filariasis. Jurnal Kesehatan Masyarakat, 7(1), 32-38.

Nabilla, U. (2020). Efektivitas Pengobatan DEC dan Doxycycline pada Transmisi Filariasis. Gamma-Pi, 2(1), 12-17.

Setyaningtyas, D. E., Yuana, W. T., \& Rahayu, N. (2017). Keberhasilan Pengobatan Massal Filariasis di Kecamatan Kusan Hulu Kabupaten Tanah Bumbu Provinsi Kalimantan Selatan. Balaba: Jurnal Litbang Pengendalian Penyakit Bersumber Binatang Banjarnegara, 13(2), 133-142.

Sihotang, W. D., Simbolon, C. C., Hartiny, J., Tindaon, D., \& Sinaga, L. P. (2019). Analisis Kestabilan Model SEIR Penyebaran Penyakit Campak dengan Pengaruh Imunisasi dan Vaksin MR. Jurnal Matematika, Statistika Dan Komputasi, 16(1), 107113. 